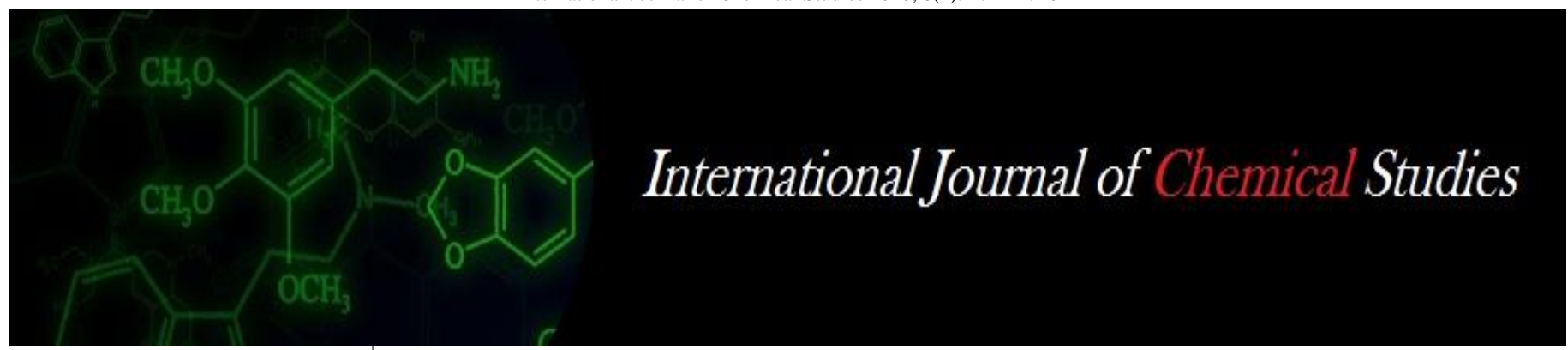

P-ISSN: 2349-8528

E-ISSN: 2321-4902

www.chemijournal.com

IJCS 2020; 8(1): 2721-2726

(C) 2020 IJCS

Received: 25-11-2019

Accepted: 27-12-2019

Sinchana NS

M.Sc. Scholar, Department of

Plantation, Spices, Medicinal and

Aromatic Crops University of

Horticultural Sciences, Bagalkot,

Karnataka, India

\section{Kattimani KN}

Department of Plantation, Spices, Medicinal and Aromatic Crops COH Bagalkot, UHS,

Bagalkot, Karnataka, India

Prabhuling G

Center for Horticulture

Biotechnology, Director of

Research, UHS Bagalkot,

Karnataka, India

Sudesh K

Department of Plantation, Spices, Medicinal and Aromatic Crops COH Bagalkot, UHS, Bagalkot, Karnataka, India

Jagadeesha $\mathbf{N}$

Department of Agronomy COH, Munirabad, Koppal, UHS,

Bagalkot, Karnataka, India

Corresponding Author: Sinchana NS

M.Sc. Scholar, Department of Plantation, Spices, Medicinal and Aromatic Crops University of Horticultural Sciences, Bagalkot, Karnataka, India

\section{Standardization of tissue culture protocol for turmeric (Curcuma longa L.) Cv. Salem}

\author{
Sinchana NS, Kattimani KN, Prabhuling G, Sudesh K and Jagadeesha N
}

DOI: https://doi.org/10.22271/chemi.2020.v8.i1ao.8681

\begin{abstract}
Turmeric Cv. Salem is the popular cultivar of turmeric growing in Tamil Nadu, Karnataka, Andhra Pradesh and Maharashtra. The demand for planting of this cultivar is huge and tissue culture technology ensures the mass production of a large quantity of disease free true-to-type plants from a single parent plant. The present study was carried during the year 2017-18 to standardize the tissue culture protocol for turmeric to obtain aseptic tissue culture plantlets. Surface sterilization of the explants was effectively achieved by $\mathrm{HgCl}_{2}$ treatment with $0.10 \%$ for 15 minutes as it resulted in highest culture establishment (59.99\%) with minimum bacterial and fungal contamination. Among the different treatments used for shoot proliferation, MS medium fortified with BAP $2 \mathrm{mg} / \mathrm{l}$ and IAA $0.2 \mathrm{mg} / \mathrm{l}$ gave significantly maximum response (94.44\%). Maximum in vitro rooting $(91.17 \%$ ) were observed with $1 / 2$ strength MS medium containing IBA $2 \mathrm{mg} / \mathrm{l}$. The rooted plantlets were hardened for 25 days under polytunnel with different media.
\end{abstract}

Keywords: Curcuma longa cv. Salem, in vitro, sprouted rhizome bud, aseptic culture

\section{Introduction}

Turmeric (Curcuma longa L.) is an herbaceous perennial herb from the Asian native belonging to Zingiberaceae family under the order Zingiberales. It is one of the most valuable and important spice crop of the world. It is cultivated for its underground rhizomes which are used in many ways viz., condiment in culinary preparation, colouring agent in textiles, as food and confectioneries. Medicinally, it acts as carminative, antiseptic and antiparasitic for many skin infections and cures the sore throat and common cold. It is broadly used as a medicine because it is rich in compounds like curcumin, sodium curcuminate and methyl-curcumin (Li et al., 2011; Ramadan et al., 2011) ${ }^{[13,21]}$. Its rhizome contains variety of pigments among which curcumin is the major pigment responsible for colour. It is the yellow colouring pigment present in rhizome which is gaining importance due to ban on artificial colours in food industry. This has been studied due to their anti- inflammatory, antioxidant and antitumor potential (Chainani-Wu, 2003; Kainsa et al., 2012; Green and Mitchell, 2014) ${ }^{[3,11,7]}$. It has also an antimicrobial effect against Aspergillus spp. fungi and bacteria from Pseudomonas, Staphylococcus and Salmonella genera (Rao and Mittal, 2014) ${ }^{[22]}$. In the cosmetics industry, it is used to produce body lotions and moisturizers, whereas in the food industry, rhizomes are used to manufacture colorings that are usually used in pasta, in the preparation of sauces and breads (Shaw and Panda, 2015) ${ }^{[25]}$. It is also commonly used in landscaping projects for gardens and parks, and in flower commerce for floral arrangements and bouquets (Velayudhan et al., 2012) ${ }^{[27]}$. In pharmaceuticals, it is valued for its anti-cancerous, anti-inflammatory and antiseptic properties. For commercial cultivation, the use of rhizome is a routine vegetative propagation method for Curcuma spp. and thus large quantity of rhizomes are required for cultivation because of the low efficiency of vegetative propagation. Turmeric rhizomes degenerate after long term propagation and it is difficult to propagate through seed because of poor flowering and seed set (Zhao, 2002) ${ }^{[28]}$. This technique presents some limiting factors for seedling production, such as cost, production time, labor and utilization of the commercialized part the rhizomes. For this reason, turmeric cultivators use at least one healthy bud containing rhizome pieces as seed. Moreover, rhizome multiplication rate is very low. In a growing season (8-10 months), only 10-15 lateral buds are produced. In addition, during storage and 
cultivation, rhizomes used for vegetative propagation are susceptible to diseases that causes tissue senescence and degeneration. Heavy losses have been reported because of infection with Ralstonia solanacearum (formerly Pseudomonas solanacearum), soft rot (Pythium aphanidermatum) and nematodes (Meloidogyne spp.) (Hosoki and Sagawa, 1977). The contamination of the propagation material with soil fungi, bacteria and nematodes present in soil is another obstacle that results in loss of the propagation material. One way to relieve these limiting factors for turmeric establishment may be through the culture medium in vegetal tissues. In vitro culture techniques provide an alternative means of propagation and is a tool for crop improvement. This technique of in vitro culture has been commercially utilized in herbaceous crops like banana, cardamom, orchids etc. Tissue culture of curcuma species was first performed by Nadgauda et al. (1978) ${ }^{[15]}$ using stem tips of Curcuma domestica. The demand for the quality planting material is being increasing rapidly. Plant tissue culture technology ensures the mass production of a large quantity of disease free true-to-type plants from a single parent plant, uniformity in production and year round production in short time. However, the research work on tissue culture multiplication in turmeric is scarce. Moreover, tissue culture protocols are specific to particular cultivars. Keeping these points in view, the present investigation "Standardization of tissue culture protocol for Turmeric (Curcuma longa L.) cv. Salem" was carried out with the objective to know the effect of Mercuric chloride on establishment of aseptic culture and to find out the effect of growth regulators on in vitro regeneration of plantlets.

\section{Materials and Methods}

The present investigation was carried out at the Center for Horticulture Biotechnology, Directorate of Research, University of Horticultural Sciences, Bagalkot 587104, Karnataka, India. Healthy and vigorously growing turmeric plants of (8-9 month's age and in active growth phase), free from viruses and diseases, was selected as a source of explants (Fig. 1.)

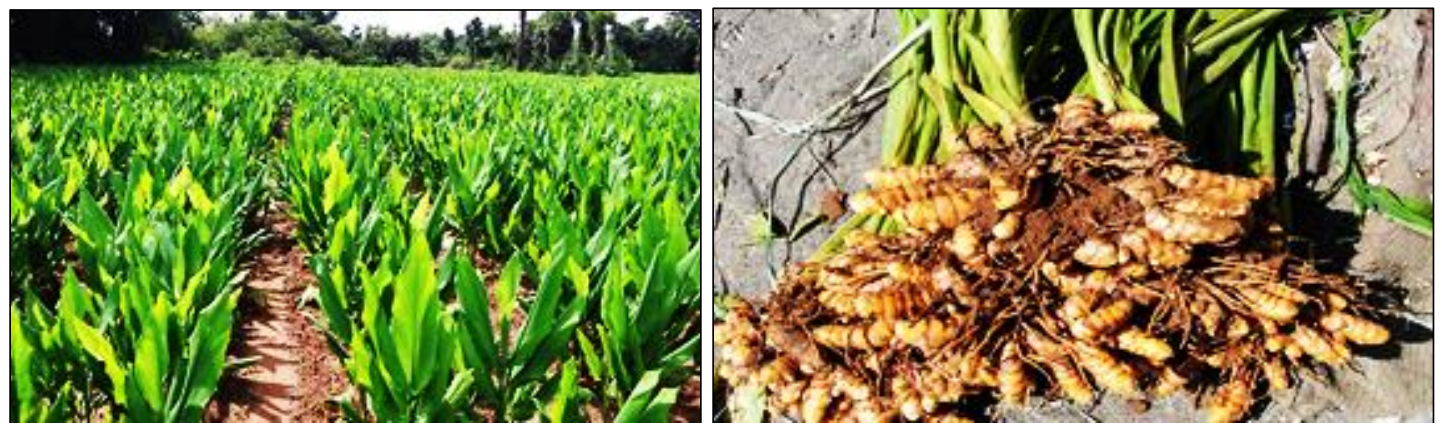

Fig 1: General view of turmeric cv. Salem in field and fresh rhizomes

\section{Preparation of explant}

The rhizomes obtained from the field were thoroughly washed in running tap water followed by washing with a detergent solution to remove adhering soil particles. Later, rhizomes were placed in moist sand for sprouting. Just sprouted shoot tips were excised and used as explants. Later, sprouted rhizomes were kept immersed in a fungicide solution bavistin 1 percent for half an hour, to further clean the rhizomes. Then the sprouted rhizome buds excised using a sterilized stainless steel knife until the length of explants was $2-3 \mathrm{~cm}$ with buds intact. Later excised rhizome bits enclosing sprouted buds were treated with solution of carbendazim (1000ppm) (Carzim-50) and Streptocycline sulphate (500ppm) (KCycline) for $30 \mathrm{~min}$ and washed with double distilled water. These explants were treated with 500ppm Cetrimide (of Himedia Company) for 30min and washed 2-3 times with double distilled water. Then they were surface sterilized with mercuric chloride (of Himedia Company) as per the experiment requirement with constant shaking in laminar airflow cabinet. Then explants were washed 4-5 times with double distilled water. Further operations such as washing several times with sterile distilled water to remove all traces of chlorine, trimming of explants and inoculation in liquid culture media were carried out under a laminar air flow chamber.

\section{Initiation of aseptic culture}

Sprouted rhizome bud explants were treated with mercuric chloride at different concentrations and durations and incubated in culture tubes $(150 \mathrm{X} 25 \mathrm{~mm})$ containing $\mathrm{MS}$ liquid culture media supplemented with $2 \mathrm{mg} / \mathrm{l}$ of BAP, $100 \mathrm{mg} / \mathrm{l}$ of adenine sulphate and $100 \mathrm{mg} / \mathrm{l}$ of ascorbic acid for 4 weeks maintaining standard culture conditions of $25 \pm 2{ }^{\circ} \mathrm{C}$ temperature, 60 percent relative humidity and photoperiodic cycle of 16 hours light and 8 hours dark period. After 4 weeks of incubation, all the explants were evaluated for their ability to establish in liquid media. Greening and swelling of the explants were utilized as important criteria for assessing the success in establishment. And they were regularly inspected for (bacterial and fungal) contamination, browning and tissue damage. Those contaminated and damaged explants were considered as non-established and discarded. Healthy and contaminant free explants were excised by removing discoloured tissue and transferred to baby jar bottles containing the MS semi-solid media as per experiment requirement and incubated for four weeks maintaining standard culture conditions mentioned as above. The explants were observed for their bulging in the tips and morphogenetic activity. Such explants were counted and expressed in terms of percent establisment. The successfully established explants were excised by trimming the discoloured tissues and then 24 vertical cuts were made at the tip of each explant (Fig. 2.) 


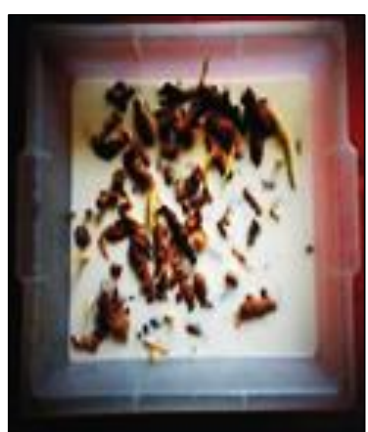

A

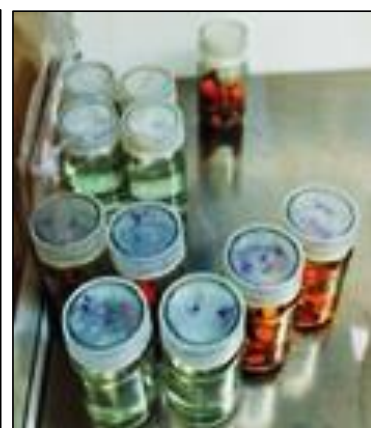

B

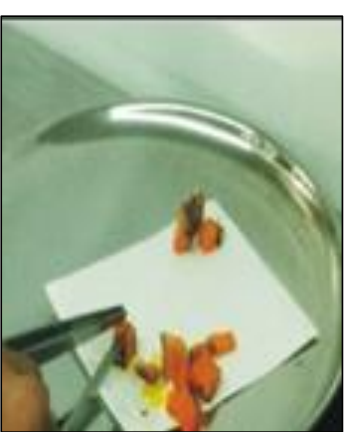

$\mathrm{C}$

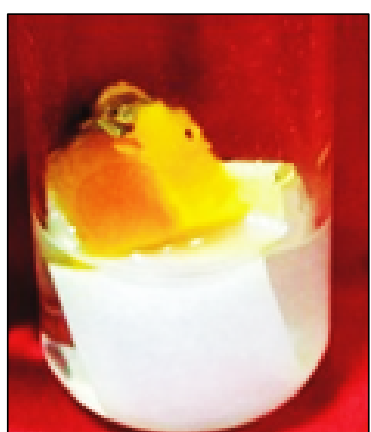

D

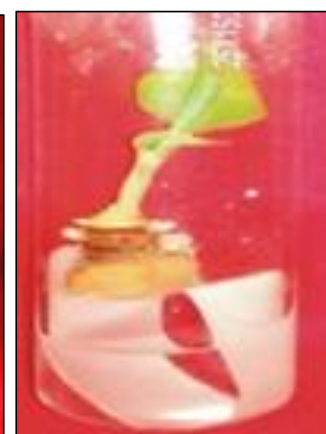

E

Fig 2: Stages in establishment of aseptic culture: A) Treating rhizomes in bavistin solution 1\%; B) Surface sterilization of excised rhizome buds with mercuric chloride; C) Excising of surface sterilized explants; D) Explant inoculated in liquid culture medium; D) Established aspectic culture on liquid medium.

\section{Effect of growth regulators on response for shoot} initiation

After initiation, healthy and contaminant free aseptic cultures were excised by removing the discolored tissue and then 2-4 vertical cuts were made at the tips of each culture and transferred to baby jar bottles containing the MS semi-solid media for 25-30 days which contained different concentrations of 6-benzylamino purine (BAP), Indole-3acetic acid (IAA) and Kinetin (Kn). All the media were autoclaved at $15 \mathrm{psi}$ and $121{ }^{\circ} \mathrm{C}$ for 20 minutes. The culture jars containing explants were incubated in growth chamber at $25 \pm 2{ }^{\circ} \mathrm{C}$ with 16 hours photoperiod provided by cool white fluorescent tubes. The successfully established cultures were excised by trimming the discolored tissue and they were longitudinally split into two equal halves and cultured in the same media for 4 weeks. The materials were 3 times sub cultured at a regular interval of four weeks into same medium.

\section{Effect of growth regulators on rooting}

After 3rd subculture cycle, individual shoots of 3-4cm length were excised and transferred onto half strength MS medium rooting media which contained different auxins such as Indole-3-acetic acid (IAA), Indole-3-butyric acid (IBA) and Naphtalene acetic acid (NAA) with $2 \mathrm{~g} / \mathrm{l}$ of charcoal at different concentrations for sufficient root regeneration. The plantlets were carefully removed from the glass jars and roots of the plantlets were gently washed under running tap water to remove agar attached to the roots. Observation on percentage response, number of primary roots/plantlet and fresh weight of plantlet were recorded.

\section{Hardening of plantlets}

In vitro grown rooted plantlets were taken out of the bottles, washed with distilled water to remove residual agar from roots. Then they were immersed in 0.5 percent aqueous solution of Bavistin for 15-20min and washed with tap water. The plantlets were transplanted to protrays containing sterilized cocopeat, perlite, Trichoderma harzianum (2 $\mathrm{g} /$ plant) and Pseudomonas fluorescence (2g/plant) kept under polytunnel for 4 weeks (Fig. 3).

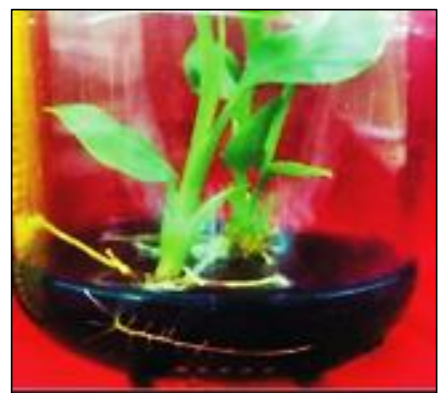

A

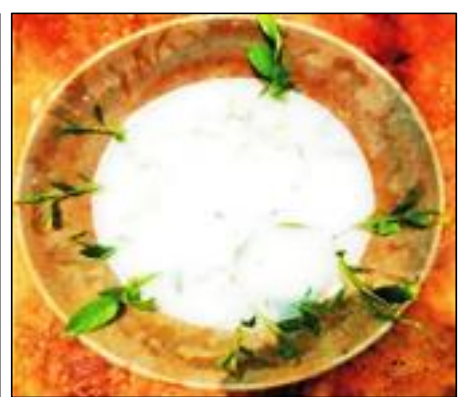

B

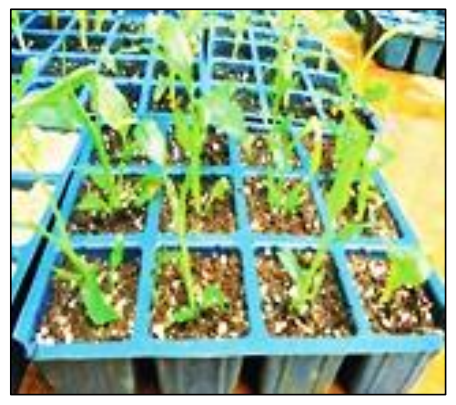

$\mathrm{C}$

Fig 3: Hardening of in vitro rooted plantlets: A) In vitro rooted plantlet; B) Treatment of in vitro rooted plantlet with bavistin solution; C) Plantlets transferred to protrays in hardening media.

\section{Statistical Analysis}

The experimental data generated was statistically analyzed in a completely randomized design by adopting analysis of variance technique. The levels of significance used for $F$ test was at 1 percent probability. Critical difference values (C.D.) values were given in the table was at 1 percent level of significance, where the F test was significant and used to compute the means. Values in percentage were subjected to arcsin transformation to ensure homogeneity. Wherever values was $100 \%$, arcsin $(100-1 / 4 n)$, where $n$ is the number of observations that make up the percentage, were substituted respectively.

\section{Results and Discussion}

Effect of mercuric chloride on establishment of aseptic culture

Contamination in tissue culture can originate from two sources, either through carryover of microorganisms present on explants surface or in tissue itself. The minimum percentage of bacterial contamination was found when sprouted rhizomes buds were treated with $0.10 \% \mathrm{HgCl}_{2}$ for 10 minutes $\left(\mathrm{T}_{2}\right), 15$ minutes $\left(\mathrm{T}_{3}\right)$ and $0.20 \% \mathrm{HgCl}_{2}$ for 5 minutes $\left(\mathrm{T}_{6}\right) \quad(9.99 \%$ each). Whereas, maximum bacterial contamination was found in $0.30 \% \mathrm{HgCl}_{2}$ for 1 minute $\left(\mathrm{T}_{9}\right)$ $(33.33 \%)$. The minimum fungal contamination was recorded 
in $0.10 \% \mathrm{HgCl}_{2}$ for 20 minutes $\left(\mathrm{T}_{4}\right)(13.33 \%)$. Whereas, maximum percent of fungal contamination was registered in untreated control $\left(\mathrm{T}_{13}\right)$ with $69.99 \%$.

In the present investigation sprouted rhizome bits treated with mercuric chloride at lower concentration and maximum exposure resulted in lower contamination (both bacterial and fungal), and culture establishment as compared to untreated control (Table 1).

This effectiveness of $\mathrm{HgCl}_{2}$ in controlling the contamination may be attributed to strong bleaching action of two chlorine atoms and mercuric ions combined strongly with protein causing death of the organism. $\mathrm{HgCl}_{2}$ is extremely poisonous due to high bleaching action of two chloride atoms and also mercuric ions which combines strongly with protein causing death of organism (Pauling, 1955) ${ }^{[18]}$. This has been reported in turmeric (Sharma et al., 2012; Ghosh et al., 2013) [23, 5], ginger (Khatun et al., 2016) ${ }^{[12]}$, mango ginger (Tamil et al.,
2012) ${ }^{[26]} \cdot \mathrm{HgCl}_{2}$ is considered as a potent surface sterilizing agent; however, its residual inhibitory effect is greater than the other sterilizing agents commonly used in plant tissue culture (Nadgauda et al., 1978) ${ }^{[15]}$.

The highest numbers of aseptic culture (59.99\%) was obtained with $\mathrm{HgCl}_{2}$ at 0.1 percent for 15 minutes. Bharalee et al. (2005) ${ }^{[2]}$ got the results using 0.1 percent $\mathrm{HgCl}_{2}$ for 15 minutes and Rehman et al. (2004) ${ }^{[20]}$ used 0.1 percent $\mathrm{HgCl}_{2}$ for 14 minutes to establish aseptic cultures in turmeric. These findings are in conformity with the results obtained by Nadgauda et al. (1983) in cardamom and De Lange et al. (1987) ${ }^{[4]}$ in ginger. The lowest aseptic cultures were obtained with untreated explants (Table 1). This lowest culture establishment may be attributed to higher contamination of cultures. These findings are in conformity with the reports in turmeric (Sharma et al., 2012) ${ }^{[23]}$ and in ginger (Jagadev et al., 2008) ${ }^{[9]}$.

Table 1: Effect of mercuric chloride on percent bacterial, fungal contamination and culture establishment in turmeric cv. Salem

\begin{tabular}{|c|c|c|c|}
\hline \multirow{2}{*}{ Treatments } & \multicolumn{2}{|c|}{ Percent contamination } & \multirow{2}{*}{ Culture establishment $(\%)$} \\
\cline { 2 - 3 } & Bacterial & Fungal & $36.66(37.24)^{*}$ \\
\hline $\mathrm{T}_{1}-0.10 \% \mathrm{HgCl}_{2}$ for 5 minutes & $16.66(23.98)^{*}$ & $43.33(41.15)^{*}$ & $53.33(46.92)$ \\
\hline $\mathrm{T}_{2}-0.10 \% \mathrm{HgCl}_{2}$ for 10 minutes & $9.99(18.18)$ & $30.00(32.89)$ & $59.99(50.82)$ \\
\hline $\mathrm{T}_{3}-0.10 \% \mathrm{HgCl}_{2}$ for 15 minutes & $9.99(18.18)$ & $16.66(23.98)$ & $53.33(46.92)$ \\
\hline $\mathrm{T}_{4}-0.10 \% \mathrm{HgCl}_{2}$ for 20 minutes & $16.66(23.98)$ & $13.33(21.41)$ & $23.33(28.82)$ \\
\hline $\mathrm{T}_{5}-0.20 \% \mathrm{HgCl}_{2}$ for 3 minutes & $13.33(21.41)$ & $49.99(44.99)$ & $26.66(30.32)$ \\
\hline $\mathrm{T}_{6}-0.20 \% \mathrm{HgCl}_{2}$ for 5 minutes & $9.99(18.18)$ & $46.66(43.08)$ & $36.66(37.24)$ \\
\hline $\mathrm{T}_{7}-0.20 \% \mathrm{HgCl}_{2}$ for 7 minutes & $16.66(23.98)$ & $29.99(33.08)$ & $29.99(33.17)$ \\
\hline $\mathrm{T}_{8}-0.20 \% \mathrm{HgCl}_{2}$ for 10 minutes & $20.00(26.56)$ & $19.96(26.23)$ & $16.66(23.98)$ \\
\hline $\mathrm{T}_{9}-0.30 \% \mathrm{HgCl}_{2}$ for 1 minute & $33.33(35.26)$ & $43.33(41.15)$ & $19.99(26.25)$ \\
\hline $\mathrm{T}_{10}-0.30 \% \mathrm{HgCl}_{2}$ for 2 minutes & $26.66(31.08)$ & $39.99(39.17)$ & $33.33(35.15)$ \\
\hline $\mathrm{T}_{11}-0.30 \% \mathrm{HgCl}_{2}$ for 3 minutes & $20.00(26.56)$ & $26.66(31.08)$ & $23.33(28.82)$ \\
\hline $\mathrm{T}_{12}-0.30 \% \mathrm{HgCl}_{2}$ for 4 minutes & $13.33(21.41)$ & $23.33(28.82)$ & $6.66(14.95)$ \\
\hline $\mathrm{T}_{13}-\mathrm{Control}($ Untreated) & $16.66(23.98)$ & $69.99(56.81)$ & 5.83 \\
\hline $\mathrm{S} . \mathrm{Em} \pm$ & 3.75 & 4.11 & 17.57 \\
\hline $\mathrm{CD}$ at $1 \%$ & 11.30 & 12.39 & \\
\hline
\end{tabular}

*The values in the parenthesis are arc sine transformed values

\section{Effect of growth regulators on shoot growth}

Incorporation of BAP alone or in combination with IAA and Kinetin into media had either a positive or negative effects on percent shoot initiation. Some explants failed to regenerate even though they were not dead. The data were recorded at the end of third subculture cycle. Among the different concentration of growth regulators tested, the highest percentage of response (94.44\%), maximum number of shoots per explants (9.85) and thicker shoots (+++) were noticed when the aseptic cultures were incubated onto MS B +BAP $2.00 \mathrm{mg} / \mathrm{l}+\mathrm{IAA} 0.20 \mathrm{mg} / \mathrm{l}\left(\mathrm{T}_{6}\right)$. Significantly the lowest percent response, minimum number of shoots and thin shoots were observed when aseptic cultures were incubated onto MS B medium without hormones $\left(\mathrm{T}_{16}\right)(36.10 \%)$. In general, effective shoot regeneration was achieved with treatment MS B +BAP $2.00 \mathrm{mg} / \mathrm{l}+\mathrm{IAA} 0.20 \mathrm{mg} / \mathrm{l}$ followed by MS B +BAP $2.00 \mathrm{mg} / \mathrm{l}+\mathrm{IAA} 0.50 \mathrm{mg} / \mathrm{l}$ (Table 2). Probably this may be attributed due to synergistic effect of BAP and IAA at 2.00 and $0.20 \mathrm{mg} / 1$, where in, BAP is known to induce cell division and differentiation and IAA induces cell elongation and cell division. Synergistic effect of auxin with cytokinin in shoot multiplication has been reported by several workers
(Jyothibhaskar et al. 1993; Rehaman et al. 2004) ${ }^{[10,20]}$. MS B supplemented with BAP $2.00 \mathrm{mg} / \mathrm{l}+\mathrm{IAA} 0.20 \mathrm{mg} / \mathrm{l}$ resulted better shoot initiation (94.44\%) of explants. These findings in confirmation with the results of Gomathy et al. (2014) ${ }^{[6]}$ who reported that the highest shoot percent and number of multiple shoots were obtained in media supplemented with BAP at $2.00 \mathrm{mg} / \mathrm{l}+\mathrm{IAA} 0.2 \mathrm{mg} / \mathrm{l}$. It is evident from the fact that with decrease in level of BAP and IAA resulted in declined in percent shoot initiation. These results are in accordance with report of Gomathy et al., (2014) ${ }^{[6]}$ in turmeric. Significantly the minimum percent shoot initiation was observed in MS B without hormones. The two cytokinins namely, BAP and Kn used in this study, the BAP proved better than $\mathrm{Kn}$ in shoot initiation from rhizomatous bud. On the other hand, mineral nutrients are being as the basic component of culture media plays a vital role in rapid growth of tissue and the quality of morphogenesis of tissue (Niedz et al., 2007) ${ }^{[17]}$. The number of shoots and thickness of shoots increased as the concentration of cytokinins increased. This may be due to the fact that the suppression of apical dominance leads to the production of more number of multiple shoots and thicker shoots. 
Table 2: Effect of growth regulators on percent shoot response, number of shoots/explant and shoot thickness in turmeric cv. Salem

\begin{tabular}{|c|c|c|c|}
\hline Treatments & Percent response & Number of shoots/ explant & Shoot thickness \\
\hline $\mathrm{T}_{1}-\mathrm{MS} \mathrm{B}+\mathrm{BAP} 1.00 \mathrm{mg} / \mathrm{l}$ & $61.11(51.41)^{*}$ & 2.58 & ++ \\
\hline $\mathrm{T}_{2}-\mathrm{MS} \mathrm{B}+\mathrm{BAP} 2.00 \mathrm{mg} / \mathrm{l}$ & $66.66(54.80)$ & 3.67 & ++ \\
\hline $\mathrm{T}_{3}-\mathrm{MS} \mathrm{B}+\mathrm{BAP} 3.00 \mathrm{mg} / \mathrm{l}$ & $72.22(58.19)$ & 4.40 & ++ \\
\hline $\mathrm{T}_{4}-\mathrm{MS} \mathrm{B}+\mathrm{BAP} 1.00 \mathrm{mg} / \mathrm{l}+\mathrm{IAA} 0.20 \mathrm{mg} / \mathrm{l}$ & $63.88(53.07)$ & 4.65 & +++ \\
\hline $\mathrm{T}_{5}-\mathrm{MS} \mathrm{B}+\mathrm{BAP} 1.00 \mathrm{mg} / \mathrm{l}+\mathrm{IAA} 0.50 \mathrm{mg} / \mathrm{l}$ & $69.44(56.46)$ & 5.10 & +++ \\
\hline $\mathrm{T}_{6}-\mathrm{MS} \mathrm{B}+\mathrm{BAP} 2.00 \mathrm{mg} / \mathrm{l}+\mathrm{IAA} 0.20 \mathrm{mg} / \mathrm{l}$ & $94.44(76.36)$ & 9.85 & +++ \\
\hline $\mathrm{T}_{7}-\mathrm{MS} \mathrm{B}+\mathrm{BAP} 2.00 \mathrm{mg} / \mathrm{l}+\mathrm{IAA} 0.50 \mathrm{mg} / \mathrm{l}$ & $86.10(68.21)$ & 7.70 & +++ \\
\hline $\mathrm{T}_{8}-\mathrm{MS} \mathrm{B}+\mathrm{BAP} 3.00 \mathrm{mg} / \mathrm{l}+\mathrm{IAA} 0.20 \mathrm{mg} / \mathrm{l}$ & $74.99(60.03)$ & 7.10 & +++ \\
\hline $\mathrm{T}_{9}$ - MS B +BAP 3.00mg/l +IAA 0.50mg/l & $58.33(49.86)$ & 5.22 & +++ \\
\hline $\mathrm{T}_{10}-\mathrm{MS} \mathrm{B}+\mathrm{BAP} 1.00 \mathrm{mg} / \mathrm{l}+\mathrm{Kn} 0.20 \mathrm{mg} / \mathrm{l}$ & $52.77(46.59)$ & 3.10 & ++ \\
\hline $\mathrm{T}_{11}-\mathrm{MS} \mathrm{B}+\mathrm{BAP} 1.00 \mathrm{mg} / \mathrm{l}+\mathrm{Kn} 0.50 \mathrm{mg} / \mathrm{l}$ & $58.33(49.86)$ & 5.40 & ++ \\
\hline $\mathrm{T}_{12}-\mathrm{MS} \mathrm{B}+\mathrm{BAP} 2.00 \mathrm{mg} / \mathrm{l}+\mathrm{Kn} 0.20 \mathrm{mg} / \mathrm{l}$ & $77.77(62.04)$ & 5.10 & ++ \\
\hline $\mathrm{T}_{13}-\mathrm{MS} \mathrm{B}+\mathrm{BAP} 2.00 \mathrm{mg} / \mathrm{l}+\mathrm{Kn} 0.50 \mathrm{mg} / \mathrm{l}$ & $55.55(48.26)$ & 3.85 & ++ \\
\hline $\mathrm{T}_{14}-\mathrm{MS} \mathrm{B}+\mathrm{BAP} 3.00 \mathrm{mg} / \mathrm{l}+\mathrm{Kn} 0.20 \mathrm{mg} / \mathrm{l}$ & $63.88(53.07)$ & 5.40 & ++ \\
\hline $\mathrm{T}_{15}-\mathrm{MS} \mathrm{B}+\mathrm{BAP} 3.00 \mathrm{mg} / \mathrm{l}+\mathrm{Kn} 0.50 \mathrm{mg} / \mathrm{l}$ & $47.22(43.40)$ & 5.90 & ++ \\
\hline $\mathrm{T}_{16}-\mathrm{MS} \mathrm{B}$ without hormones & $36.10(36.91)$ & 2.15 & + \\
\hline S. Em \pm & 4.20 & 0.18 & - \\
\hline $\mathrm{CD}$ at $1 \%$ & 12.29 & 0.56 & - \\
\hline
\end{tabular}

*The values in the parenthesis are arc sine transformed values MS B-Murashige \& Skoog's basal medium

+: Thin, ++: Medium thick, +++: Thick

In the present study, higher concentration of BAP and BAP $+\mathrm{Kn}$ generally reduced the in vitro regeneration. Probably this may be due to the inhibitory effect of cytokinins on in vitro regeneration at higher concentrations. The results revealed that the multiple shoot formation was more in combination of BAP and IAA. Similar results were observed in Curcuma longa (Nasirujjaman et al., 2005; Gomathy et al., 2014 and Bejoy et al., 2006) ${ }^{[16,6,1]}$.

\section{Effect of growth regulators on in vitro root growth}

The results regarding the percent response rooting found to be significant. Root initiation was found maximum in IBA than IAA and NAA supplemented media. The maximum percent rooting $(91.17 \%)$, maximum numbers of primary roots per shoot (2.70) and highest fresh weight of plantlet (1.80 $\mathrm{g} /$ plantlet) were recorded in treatment $1 / 2 \mathrm{MS} \mathrm{B}+\mathrm{IBA}$ $2.00 \mathrm{mg} / \mathrm{l}\left(\mathrm{T}_{4}\right)$ and the minimum rooting, number of primary roots per shoot and lowest fresh weight were recorded in $1 / 2$ MS B without hormones $\left(\mathrm{T}_{13}\right)(38.23 \%)$. In the present investigation, the in vitro developed shoots were used for root induction. Half strength MS B proved superior in promoting in vitro root growth. Half strength MS B supplemented with higher level of IBA $(2.00 \mathrm{mg} / \mathrm{l})$ showed significantly maximum rooting with better root growth (Table 2). This may be attributed to higher effectiveness of IBA in promoting root growth as it was effectively absorbed and utilized. The auxins, which most frequently incorporated in the basal media to induce rooting are IAA, IBA and NAA. Of the three auxins tried, IBA was found to be most promising growth regulator followed by NAA and IAA. Plantlets regenerated on $1 / 2$ MS B +IBA $2.00 \mathrm{mg} / \mathrm{l}$ showed maximum fresh weight. Increase in fresh weight may be attributed to enhanced growth of tissue cultured turmeric in terms of more shoots/explants and more number of primary and secondary roots. Similar results were also obtained with IBA $2.00 \mathrm{mg} / \mathrm{l}$ by Sharmin et al. (2013) ${ }^{\text {[24] }}$ in turmeric however contradictory results were reported by Meenakshi et al. (2001) ${ }^{[14]}$ in turmeric and Prabhuling et al. (2017) ${ }^{[19]}$ in banana, who observed maximum rooting and highest root length with NAA.

Table 3: Effect of growth regulators on number of primary roots per plantlet and Fresh weight of plantlet (g/plantlet) in turmeric cv. Salem

\begin{tabular}{|c|c|c|c|}
\hline Treatments & Percent rooting & Number of primary roots/plantlet & Fresh weight of plantlet (g/plantlet) \\
\hline $\mathrm{T}_{1}-1 / 2 \mathrm{MS}$ B +IBA $0.50 \mathrm{mg} / \mathrm{l}$ & $67.64(55.35)^{*}$ & 2.10 & 0.95 \\
\hline $\mathrm{T}_{2}-1 / 2 \mathrm{MS}$ B +IBA $1.00 \mathrm{mg} / \mathrm{l}$ & $73.52(59.06)$ & 2.19 & 1.29 \\
\hline $\mathrm{T}_{3}-1 / 2 \mathrm{MS} \mathrm{B}+\mathrm{IBA} 1.50 \mathrm{mg} / \mathrm{l}$ & $79.41(63.07)$ & 2.54 & 0.99 \\
\hline $\mathrm{T}_{4}-1 / 2 \mathrm{MS}$ B +IBA $2.00 \mathrm{mg} / \mathrm{l}$ & $91.17(72.94)$ & 2.70 & 1.80 \\
\hline $\mathrm{T}_{5}-1 / 2 \mathrm{MS}$ B +IAA $0.50 \mathrm{mg} / \mathrm{l}$ & $61.76(51.81)$ & 2.38 & 1.59 \\
\hline $\mathrm{T}_{6}-1 / 2 \mathrm{MS}$ B +IAA $1.00 \mathrm{mg} / \mathrm{l}$ & $70.58(57.26)$ & 2.30 & 0.95 \\
\hline $\mathrm{T}_{7}-1 / 2 \mathrm{MS}$ B +IAA $1.50 \mathrm{mg} / \mathrm{l}$ & $76.46(61.15)$ & 2.13 & 0.88 \\
\hline $\mathrm{T}_{8}-1 / 2 \mathrm{MS} \mathrm{B}+\mathrm{IAA} 2.00 \mathrm{mg} / \mathrm{l}$ & $73.52(59.06)$ & 1.78 & 0.41 \\
\hline $\mathrm{T}_{9}-1 / 2 \mathrm{MS}$ B +NAA 0.50mg/l & $52.94(46.68)$ & 1.89 & 0.65 \\
\hline $\mathrm{T}_{10}-1 / 2 \mathrm{MS}$ B +NAA 1.00mg/l & $58.82(50.08)$ & 2.15 & 0.67 \\
\hline $\mathrm{T}_{11}-1 / 2 \mathrm{MS} \mathrm{B}+\mathrm{NAA} 1.50 \mathrm{mg} / \mathrm{l}$ & $64.70(53.54)$ & 2.26 & 1.06 \\
\hline $\mathrm{T}_{12}-1 / 2 \mathrm{MS}$ B +NAA $2.00 \mathrm{mg} / \mathrm{l}$ & $55.88(48.38)$ & 1.80 & 0.58 \\
\hline $\mathrm{T}_{13}-1 / 2 \mathrm{MS} \mathrm{B}$ without hormones & $38.23(38.17)$ & 1.47 & 0.33 \\
\hline S. Em \pm & 3.77 & 0.04 & 0.05 \\
\hline $\mathrm{CD}$ at $1 \%$ & 11.37 & 0.14 & 0.17 \\
\hline
\end{tabular}




\section{Conclusion}

The findings of present study demonstrate that the higher establishment of aseptic culture by surface sterilization of sprouted rhizome buds, maximum shoot proliferation and maximum root growth could be achieved with $0.10 \% \mathrm{HgCl}_{2}$ for 15 minutes, MS medium containing BAP $2.00 \mathrm{mg} / 1+\mathrm{IAA}$ $0.20 \mathrm{mg} / \mathrm{l}$ and $1 / 2 \mathrm{MS}+\mathrm{IBA} 2.00 \mathrm{mg} / \mathrm{l}$ respectively. This protocol could be employed for large scale in vitro regeneration of disease free planting of turmeric cv. Salem.

\section{References}

1. Bejoy M, Dan M, Anish NP. Factors affecting the in vitro multiplication of the endemic Zingiber Curcuma haritha Mangaly and Sabu. Asian. J Plant. Sci. 2006; 5:847-853.

2. Bharalee $\mathrm{R}$, Das $\mathrm{A}$, Kalita $\mathrm{MC}$. In vitro clonal propagation of Curcuma caesia Roxb. and Curcuma zedoaria Rosc. from rhizome bud explants. J Pl. Biochem. Biotechnol. 2005; 14:61-63.

3. Chainani-Wu N. Safety and anti-inflammatory activity of curcumin: a component of tumeric (Curcuma longa). J. Altern. Complem. Med. 2003; 9(1):161-168.

4. De Lange JH, Willers $\mathrm{P}$, Nel $\mathrm{M}$. Elimination of nematodes from ginger (Zinger officinale Roscoe) by tissue culture, J Hort. Sci. 1987; 62:249-252.

5. Ghosh A, Chatterjee P, Ghosh P. A protocol for rapid propagation of genetically true to type Indian turmeric (Curcuma longa L.) through in vitro culture technique. Adv. Appl Sci Res. 2013; 4(3):39-45.

6. Gomathy $\mathrm{V}$, Anbazhagan $\mathrm{M}$, Arumugam $\mathrm{K}$. In vitro propagation of Curcuma longa (Turmeric). Int. J Res. Pl. Sci. 2014; 4(1):30-33.

7. Green CE, Mitchell SA. The Effects of blanching, harvest time and location (with a minor look at postharvest blighting) on oleoresin yields, percent curcuminoids and levels of antioxidant activity of turmeric (Curcuma longa) rhizomes grown in Jamaica. Mod. Chem. Appl. 2014; 2(140):2-9.

8. Hosoki T, Sagawa Y. Clonal propagation of ginger (Zingiber officinale Rosc.) through tissue culture. Hort Science. 1977; 12(5):451-452.

9. Jagadev PN, Panda KN, Beura S. A fast protocol for in vitro propagation of ginger (Zingiber officinale Rosc.) of a tribal district of India. Acta Hort, 2008, 101-107.

10. Jyothibhaskar, Aravindakshan M, Valsalakumari PK, Rajeevan PK. Micropropagation studies in banana. South Indian Hort. 1993; 64:186-191.

11. Kainsa S, Kumar P, Rani P. Medicinal plants of Asian origin having anticancer potential short review. Asian J Biomed. Pharm. Sci. 2012; 2(10):01-07.

12. Khatunmm, Tanny T, Razzak AM, Alam MF, Uddin ME, Rahul M et al. Standardization of in vitro sterilization procedures for micropropagation for ginger (Zingiber officinale Rosc.). Int. J appl Biol Pharm Technol. 2016; 7:131-137.

13. Li S, Yuan W, Deng G, Wang P, Yang P. Chemical composition and product quality control of turmeric (Curcuma longa L.). Pharm. Crop. 2011; 2 (1):28-54.

14. Meenakshi N, Sulikeri GS, Krishnamoorthy V, Ramakrishna VH. Standardization of chemical environment for multiple shoot induction of turmeric (Curcuma longa L.) for In vitro clonal propagation. Crop Research. 2001; 22:449-453.

15. Nadgauda RS, Mascarenhas RM, Hendre RR, Jagannathan V. Rapid multiplication of turmeric
(Curcuma longa Linn.) plants by tissue culture. Indian J. Exp. Biol. 1978; 16:120-122.

16. Nasirujjaman K, Uddin MS, Zaman S. Reza MA. Micropropagation of turmeric (Curcuma longa Linn.) through in vitro rhizome bud culture. J Biol. Sci. 2005; 5 (4):490-492.

17. Niedz RP, Evens TJ. Regulating plant tissue growth by mineral nutrition. In vitro Cell. Dev. Biol. Plant. 2007; 43:370-381.

18. Pauling L. College Chemistry, W. H. Freeman and Company, San Francisco, 1955, 578.

19. Prabhuling G, Rashmi H, Babu AG. Protocol for tissue culture propagation of banana cv. Ney poovan (AB). Int. J Sci. Nat. 2017; 8(4):882-887.

20. Rahmanmm, Amin MN, Jahan HS, Ahmed R. In vitro regeneration of plantlets of Curcuma longa $\mathrm{L}$. a volume spice plant of Bangladesh. Asian J Pl Sci. 2004; 3:306309.

21. Ramadan G, Al-Kahtani MA, El-Sayed WM. Antiinflammatory and anti-oxidant properties of Curcuma longa (turmeric) versus Zingiber officinale (Ginger) rhizomes in rat adjuvant-induced arthritis Inflammation. 2011; 34(4):291-301.

22. Rao N, Mittal S. An in vitro evaluation of the antimicrobial activity of Curcuma longa against selected pathogenic microorganisms. Res. J Sci. Technol. 2014; 6(2):71-74.

23. Sharma SK, Sharma M, Singh AK, Raina V, Lal AM. In vitro protocol standardization for turmeric multiplication in Jammu Division. Asian J Hort. 2012; 7(1):151-153.

24. Sharmin SA, Alam MJ, Sheikhmm I, Zaman R, Khalekuzzaman M, Mondal SC et al. Micropropagation and antimicrobial activity of Curcuma aromatica Salisb., a threatened aromatic medicinal plant. Turk. J Biol. 2013; 37:698-708.

25. Shaw P, Panda S. Spices commonly consumed in west Bengal India-An appraisal. Int. J Life Sci. 2015; 4(2):129-133.

26. Tamilcm, Sundram M, Suffan M, Khalid N. Optimization of culture condition for callus induction from shoot buds for establishment of growing cell suspension cultures of mango ginger (Curcuma mangga). Australian J Crop Sci. 2012; 6(7):1139-1146.

27. Velayudhan KC, Dikshit N, Nizar MA. Ethnobotany of turmeric (Curcuma longa L.). Indian J Tradit. Knowl. 2012; 11(4):607-614.

28. Zhao DW, High quality and production of ginger-theory and technology. China Agricultural Publishing Company, Beijing, 2002, 10-30. 